\title{
Technology and Mediated Instruction
}

\author{
ISSUE HIGHLIGHTS:
}

\section{FIRST INTERNATIONAL CONFERENCE ON FOREIGN LANGUAGE EDUCATION AND TECHNOLOGY (FLEAT)}

\author{
USA \\ Joseph H. Sheehan \\ President, National Association of \\ Learning Laboratory Directors
}

\author{
JAPAN \\ Takashi Kuroda \\ President, Language Laboratory \\ Association of Japan
}

\author{
Tokyo, Japan \\ Okura Hotel \\ August - 18-21, 1981
}

Dale V. Lally Jr, Issue Editor

Journal of the National Association of Learning Laboratory Directors Volume 15, Number $3 / 4$

Spring 1981 


\section{NALLD JOURNAL \\ TECHNOLOGY AND MEDIATED INSTRUCTION}

NALLD JOURNAL: TECHNOLOGY AND MEDIATED INSTRUCTION (ISSN 0027-5905) is currently published three times annually (Fall, Winter, Spring/Summer) by the National Association of Learning Laboratory Directors (NALLD). Membership in the Association is open to anyone associated with or interested in furthering the effective use of media in all areas of instruction. The membership year begins on October 1st and includes a personal subscription to the JOURNAL.

Opinions expressed in signed articles are those of the authors and not necessarily of NALLD. Although NALLD attempts to screen advertising for integrity, all advertising remains the responsibility of the advertiser. Neither opinions nor advertising carry NALLD approval unless adopted by the NALLD Executive Board. The NALLD JOURNAL is indexed in the CURRENT INDEX OF JOURNALS IN EDUCATION and is cited in LANGUAGE AND LANGUAGE BEHAVIORAL ABSTRACTS.

RATES. North America $\$ 10$; all other areas $\$ 15$; students $\$ 5$. Sustaining members $\$ 100$. Institutional subscription $\$ 15$. Back issues are $\$ 5$ each. This publication is also available on microfilm from: University Microfilms International, 300 North Zeeb Road, Dept. P.R., Ann Arbor, MI 48106 or 30-32 Mortimer St., Dept. P.R., London WIN 7RA England.

Manuscripts submitted for review should be double-spaced and sent in triplicate to NALLD JOURNAL, A \& S Learning Lab., Bingham Humanities 16, University of Louisville, Louisville, Kentucky, 40292. Submissions should follow the guidelines of the PUBLICATIONS MANUAI. of the American Psychological Association (1974, rev) and/or A MANUAl. OF STYLE, University of Chicago Press (12th ed.). However, the editors recognize and accept the MLA format.

Dues, subscriptions, changes of address, and orders for back issues should be sent to: Academic Publications, University of Louisville, Louisville, Ky, 40292, U.S.A. Payment is required in U.S. funds drawn on U.S. or Canadian banks. Make all checks payable to NALLD.

Advertising queries should be sent to Dr. Les Bailey, Advertising Manager, NALLD JOURNAL: TECHNOLOGY AND MEDIATED INSTRUCTION, Room 48B, Kresge Centennial Hall, Northwestern University, 1859 Sheridan Road, Evanston, Illinois, 60201, U.S.A.

POSTMASTER: Send Form 3579 to NALLD, Academic Publications, University of Louisville, 2301 South Third Street, Louisille, Ky, 40292, U.S.A.

Third class postage paid at Louisville, Kentucky.

Copyright 1981 by the National Association of Learning Laboratory Directors. 
NALLD

Journal

of

Technology

and

Mediated

Instruction

President

Joseph H. Sheehan

University of

Houston

Vice President

Victor Aulestia

University of

Maryland-Baltimore

County

Executive Sec'y

Samuel Burggraaf

Brigham Young

University

Treasurer

Leslie Bailey

Northwestern

University

Recording Sec'y

Jackie Tanner

Georgetown

University

Journal Editor

Dale V. Lally Jr.

University of

Louisville

\section{CONTENTS}

Expectation of the

International Conference

Spotlight on - Language

Laboratory Association of Japan

9

FLEAT Committee Members

Learning Laboratory Directors

Toyko - What To Do and How To Do It

FLEAT Conference

by Event Numbers

Program

A Guide to the use of the

List of FLEAT Participants

39

Personal Plan For Conference

98 
NALLD JOURNAL:

Technology and Mediated Instruction

Journal of the National Association of Learning Laboratory Directors

Volume 15 , Number $3 / 4$

Spring, 1981

$\begin{array}{ll}\text { Editor-in-Chief } & \text { Dale V. Lally Jr, University of Louisville } \\ \text { Co-Editor } & \text { Denzil Edge, University of Louisville } \\ \text { Co-Editor } & \text { James Eiseman, University of Louisville } \\ \text { Co-Editor } & \text { Robert N. St. Clair, University of Louisville } \\ \text { Associate Editors } & \begin{array}{l}\text { Charles P. Richardson, Ohio University } \\ \text { Flint Smith, Purdue University }\end{array} \\ \text { Advertising Manager } & \text { Leslie Bailey, Northwestern University }\end{array}$

\section{DEPARTMENTS}

Off-the-Air

Reviews

Edmun Richmond, Georgia Institute of Technology

Conference Updates

NALLD News Stephen Spangehl, University of Louisville

Dale V. Lally Jr, University of Louisville

Editors

\section{INTERNATIONAL EDITORIAL CONSULTANTS}

$\begin{array}{ll}\begin{array}{ll}\text { Liliana Baltra } \\ \text { Centro de Perfeccionamiento, } \\ \text { Experimentacion e investigaciones }\end{array} & \begin{array}{l}\text { Takashi Kuroda } \\ \text { Language Laboratory Association } \\ \text { of Japan } \\ \text { English Literature Department }\end{array} \\ \text { Casilla 16162 } & \begin{array}{l}\text { Otsuma Womens College } \\ \text { Santiago 9, Chile }\end{array} \\ \begin{array}{l}\text { 12, 3- Bancho, Chiyoda-ku } \\ \text { Tokyo, 102, Japan }\end{array} \\ \text { Yakov Borisovich Krupatkin } & \text { Reinhold Freudenstein } \\ \text { u.I. Odesskaja 1, kv. 19 } & \text { Foreign Language Research } \\ \text { Sebastopol 335000, USSR } & \text { Information Center } \\ & \text { Lahnberge } \\ & \text { D-3550 Marburg/Lahn } \\ & \text { Federal Republic of Germany }\end{array}$

